\title{
Constant Esthetic in Erode Textures of Holy Shrine Surrounding
}

\author{
Rokhsaneh Derakhshesh Nia \\ Department of Urbanism, Faculty of Art and Architecture, Imam Reza International University, Mashhad, Iran \\ Email address: \\ D.rokhsaneh@yahoo.com
}

\section{To cite this article:}

Rokhsaneh Derakhshesh Nia. Constant Esthetic in Erode Textures of Holy Shrine Surrounding. International Journal of Science, Technology and Society. Special Issue: Research and Practice in Architecture and Urban Studies in Developing Countries.

Vol. 3, No. 2-1, 2015, pp. 103-106. doi: 10.11648/j.ijsts.s.2015030201.30

\begin{abstract}
The erode textures of modern cities subject has made the different areas decision-makers and civic managers to rebuild them erode textures of holy shrine surroundings re-building has caused new-building importance twice due to lack of taking care of it causes. This has happened due to decrease in tourism attraction and social security, identify removal, economic stagnancy, as well as distrust. This paper, discusses the key items of importance to rebuild and new build of erode textures of holy shrine surrounding using constant esthetic approach in the highly reputed cultural and religious Islamic city of Mashhad, Iran.
\end{abstract}

Keywords: Sustainable Aesthetics, Distressed, Shrine

\section{Introduction}

Although the physiognomy of city, is the first manifestation of it that remains in citizens mind and memory but it has been forgot by the urban planners and managers and there is no comprehensive program for it. Our old traditional textures was been fully balanced and compared to beliefs and needs of people. Hastily economic, social cultural and architectural growth trend swift changing and new ideas and designs in architecture, have removed the last harmony and modernism of today physiognomy of cities. The green esthetic is composed of constant esthetic creation and deleting anti-esthetic cities factors. This necessity of beauty, is the most unknown necessity. "Some people has this necessity "Mazlou says [1] this kind of people become sick after seeing unattractive view, and they will be created after seeing nice environment. There has been a close relation among human being nature and architecture, in the last, architecture was a link and a relation bridge between nature and human being and guaranteed human eternity Nowadays, the fourth factor is interferer factor i.e. technology. This factor can fade or boost the other factors. The fourth factor must compare to native architecture region and identity of people. This research tries to solve problems of holy shrine surrounding texture by considering different ideas of solution.

\section{Theoretical Foundation}

In Persian language beauty means elegance and tenderness. According to Leon Battista Alberti in the book the (art of building credit), beauty is a harmony members of vulnerable. Increasing and decreasing or any changing of this is forbidden and will terminate etc.[2] At the beginning of 20th century Aldoleopold, American environment protection fan, developed ecology beauty, his approach based on environment ethical.

He believes integrity, beauty and constancy makers of social life are correct, otherwise are incorrect this theory will develop our thoughts beauty experience and will change our thoughts from visual-prompt delight to comprehensive think.

"This theory derives from base differences between appearance beauty experience based on already information". Bell says current think and appearance ecological power.

More beauty ecological healthiness Indexes nature deep discovery such as wild species resulted in deep satisfy of appearance look and locality soul perception. Beauty begins with nice objects and ended ecological healthiness appearance abilities.

Therefore, a relation is produced between processes and cultural-natural patterns to discover beauty. This relation includes our base appearance structure cycle perceptions, too. "the best beauty grade will be experience, if we can mean countenance-appearance, determine our situation in it." Bell 
says [3] Constant urban countenance theoretical base is green or ecological esthetic that respects environment

A)Operation role [3]:

In-out separator crust of the façade, Ocular

B) Esthetic role:

It states about planning and ecological esthetic.

Perception mental esthetic role. Mental clear image and affirmative effect producer on viewer

C) Environment esthetic role:

1) Inactive conformity to environment, using of ordinary technology.

2) Active conformity to environment, using of advanced technology.

\section{Aesthetic Evolution Theory}

The template is used to format your paper and style the text. All margins, column widths, line spaces, and text fonts are prescribed; please do not alter them. You may note peculiarities. For example, the head margin in this template measures proportionately more than is customary. This measurement and others are deliberate, using specifications that anticipate your paper as one part of the entire publication, and not as an independent document. Please do not revise any of the current designations [3].

Theorist standpoint of esthetic adapted from realities-imagination urbanism book written by Fransovaz Shovay, translated by M,Habibi [5] is presented in table 1 .

Table 1. Theorist standpoint of esthetic.

\begin{tabular}{|c|c|c|c|}
\hline criticizes & Time & Beliefs & \\
\hline $\begin{array}{l}\text { Conniving At } \\
\text { Industry Epoch } \\
\text { and Time soul }\end{array}$ & 19 century & $\begin{array}{l}\text { Guteek religious architecture believe in city generality } \\
\text { opposed to modern technology city production is like } \\
\text { handicrafts }\end{array}$ & $\begin{array}{l}\text { Body } \\
\text { esthetic }\end{array}$ \\
\hline Urbanism only & & Form is operation follower (louee saliva & \\
\hline & & & Operational \\
\hline $\begin{array}{l}\text { architecture free } \\
\text { from time and } \\
\text { locality }\end{array}$ & Century 20 & $\begin{array}{l}\text { The thing is not operational cannot be beautiful Ato Vagner } \\
\text { Right angle and plain volumes makers followers Loukow } \\
\text { Rebouzien }\end{array}$ & esthetic \\
\hline Century20 & $\begin{array}{l}\text { perceptional urbanism founder Lench } \\
\text { City countenance mental image clearance city } \\
\text { perception }\end{array}$ & $\begin{array}{l}\text { Believe in using structure and Modern-complicated } \\
\text { technology } \\
\text { Just and only native" right } \\
\text { Perceptional urbanism Founder Leench } \\
\text { City countenance Mental image clearance city perception }\end{array}$ & $\begin{array}{l}\text { Functional } \\
\text { aesthetics }\end{array}$ \\
\hline Century20 & $\begin{array}{l}\text { Building are not statue, full of meanings eelyard, there } \\
\text { is a difference between form and countenance trip } \\
\text { many building produce Quality Androuse }\end{array}$ & $\begin{array}{l}\text { How to know sign and beauty factors art beside operation } \\
\text { sent +modernism past, present, future symbol of esthetic and } \\
\text { solidarity }\end{array}$ & $\begin{array}{l}\text { Aesthetic } \\
\text { perception }\end{array}$ \\
\hline Century 21 & $\begin{array}{l}\text { Intelligent growth energy consumption decrease } \\
\text { Usage mixing public transport } \\
\text { Water and plant make environment life quality high } \\
\text { Urban village development: low density natural views }\end{array}$ & & $\begin{array}{l}\text { Ecologic } \\
\text { esthetic }\end{array}$ \\
\hline
\end{tabular}

\section{Holiday Shrine Surrounding Erode Texture}

In order to equip city center of Mashhad and to meet millions passengers and pilgrims needs to establish equilibrium among Holy Shrine values to urban arrangement. Rebuilding and new building of Holy Shrine surrounding texture studies and surveys have been presented.[6]

The main purpose is

1) residence-commercial usage

2) Circular net and Axlal Street making to meet pilgrim's needs.

\subsection{Holy Shrine Surrounding Texture Rebuilding New Building Public-General Purposes}

The main purposes include: Holy Shrine religious-cultural role emboss, Holy Shrine unique value Importance Increasing and emphasize on it.

Determining and stabilizing of holy shrine international, national, and local. Contemporary environment creation for pilgrim's rituals high quality urban elegance complexion creation suit to holy Shrine. New building desire creation of people appropriate social situation creation to holy Shrine.

Urban environment quality increasing necessary conditions creation for cultural-religious doing duty.

\subsection{Holy Shrine Surrounding Texture Body Esthetic Reasons of Usage}

- Economic motive and investment

- Income making and forbidden usages of residents areaboundant.

- Besides texture resident population, passenger population is important too.

- Increased value of estates and project are very high.

- Spiritual and material motives of residents-presence continuation in texture are very high.

\subsection{Constant Esthetic Creation, Use of Native Architecture}

Traditional rich culture of developing countries such as Africa Oceania resulted in fast changing after west modern culture entering the above countries, these changes caused problems and dissatisfactions [7].

The only solution of solving these problems was again attention and regard to the architecture before usurer and land 
devours architecture culture.

Holy Shrine surrounding erode texture, unfortunately.

\subsection{Body Esthetic Approach of Holy Shrine Surrounding Texture Problems}

Table 2. Analysis of existing condition and solutions.

\begin{tabular}{l} 
solution \\
\hline Harmony among main line of façade and suit \\
materials must be noticed \\
Human scale in first floor should be noticed at \\
least. natural structure protection and land \\
specifications should be noticed in order to \\
Using of façade making materials: roof-wall \\
separation shouldn't be possible easily \\
Multi comprehensive method application to meet \\
pilgrims demands and facilities present and \\
future \\
Priority to pedestrian limiting rider speed in order \\
to have high security \\
Appropriate to texture building laws approve \\
Appropriate to religious texture façade making \\
laws approve \\
Brick working of sidewalks instead of using new \\
materials \\
Appropriate to Holy Shrine texture native \\
architecture using of Ares on façade \\
Good light and illumination application in order \\
to create high quality spiritual space \\
Creation neighbor's harmony using common \\
design patterns
\end{tabular}

Standard native materials using appropriate to culture geography and history

\section{Weak points}

Out of harmony-arrange building resulted from ugly ocular countenance

Lack of Human scale in façade resulted in sense

Ocular esthetic

decrease of people to texture adjacent building ugly

No separation of building crust

Reservoirs, bathrooms, caravanserais, becoming obsolete

Excess commercial and residence users and shortage

Operational esthetic

of space for pilgrims

Traffic problems

Out of harmony building and structure

Resulted in: Lack of mental image pilgrims of Holy

Shrine texture

Undesirable perceptional mental countenance resulted

from building's façade disorder

Out of order building

Causes reminiscent spaces invading

Lack of Islamic Iranian architecture principals,

resulted in cutting of present and past architecture.

High, density of building resulted in human scale deleting

Ocular distraction resulted from out of harmony

adjacent buildings.

Air pollution and bad materials resulted

In building's façade erode

Perceptional esthetic

\author{
fog on the panes resulted from liquidity \\ _city pollution particles effects on the External \\ surface of building and stain creation on the facade. \\ External surface of buildings and stain creation on \\ the façade. \\ _In-out temp difference Lack of suit planting no \\ attention to cleaning sidewalk gardens. \\ out of harmony using of new materials. \\ Invading weather moderating gardens. \\ _holy shrine texture stone façade earthquake damages \\ intensify resulted from using stone on façade. \\ -using stone imposes high expense and wasting \\ energy green space.
}

Environmental esthetic attention to urban-design ecologic esthetic

_Nature shapes development in the city

Pay attention to public transportation using of sunlight on the roofs modern/green buildings creation

Water proof and unit-sediment façade usage

\section{Discussion and Conclusion}

Deformity and confusion that pervades the body tissue surrounding the shrine that will get rid of the hard work and time. The variety and diversity in style and form has led to confusion a gift and lack of identity tissue, inhuman, uncoordinated and unorganized citizens. Urban landscape is one issue surrounding tissue Imam Reza Holy Shrine in Mashhad, especially considering the high volume of visitors is less considered. So that every day can be distracted through the passages surrounding tissue and look at the face of the tissue that forms part of the identity of Mashhad. Mismatch between the size and height of buildings, use of design patterns and color transitions materials and divergent views on the elements involved in the face of the city buildings is confusing and inconsistent with each other, building construction and materials, including examples of this are the passages the ugly face and upset the tissue surrounding the shrine. Among other factors that the shrine damage to 
surrounding tissue Rybayy the lack of attention to the climate and canvas materials are gained. In the meantime it appears that due to the hot climate and arid climate of Mashhad need strongly felt. Also, due to the high density of the tissue around the holy shrine of new materials considered essential. The facilities overs canvas materials have created in this way opens the door to sustainability and aesthetics are green. The research is to develop ways to improve the physical tissue.

\section{References}

[1] Abraham H. Maslow, "A Theory of Human Motivation," Psychological Review, Vol. 50, 1943, pp. 370-396.

[2] Simon Bell, B. Amin Zadeh, (2007) perspective, pattern, perception and process, Tehran University, Institute for Publishing.

[3] Golkar, Koorosh. (2000)."Component of Quality of Urban Planning", Publication Research Soffeh 38: 32-65.
[4] Golkar Cyrus (2001), the parameters of quality of Urban Design, general journal, Issue 32.

[5] Shuai, Francoise (1998) Urban: facts and fiction, translation Seyed Mohsen Habibi, Tehran, Tehran University.

[6] Madani Poor, Ali. (2000) Urban Space Planning: Review of social and spatial processes, Tehran, Pardazesh and Barnameh Rizi Shahri Company.

[7] Bahraini, Sayed Hussain (1998). The process of urban design, Tehran University Press, third edition.

[8] Danesh, Jaber, and Tayebi Emir (2001) Presence in the urban Square with emphasis on traditional models of Iran, Iranian-Islamic Urban Studies, No. IV, summer.

[9] Habibi, Kiomars, Safdarnejad, Hamid Reza Mousavi, (2012),Native-Culture Based Organizing and Urban Planning of Imam Zadeh Do-Khatoon Square of Shahre-Kord City, Journal of Iranian-Islamic Urban Studies, No. VIII summer.

[10] M. Young, the Technical Writer's Handbook. Mill Valley, CA: University Science, 1998. 